\title{
Welding Processes in Low Viscosity Kimberlite Magmas: Differences to Silicic Magmas
}

\author{
R.J. Brown, B. Buse, R.S.J. Sparks \& M. Field \\ Department of Earth Sciences, Wills Memorial Building, University of Bristol, Queen's Road, \\ Bristol, BS8 1RJ, UK
}

Welding of pyroclastic material comprises two different and independent processes, namely sintering together of hot clasts at point contacts (Guest and Rogers 1967) and deformation of hot clasts accompanied by densification involving reduction of pore space (Smith 1960). Welded rocks are common in proximal volcanic environments due to the small heat loss experienced by the pyroclasts prior to deposition. Welded rocks can be difficult to interpret and in some cases it can be hard to discriminate between highgrade welded ignimbrites and coherent effusion-fed lavas or between welded fall deposits and welded ignimbrites.

In this work, we detail compositional, structural and petrographic evidence from two kimberlite fields in South Africa (Venetia K2) and Botswana (Damtshaa BK/9) that indicates that some coherent kimberlite rocks are welded deposits, as first raised by Sparks et al. (2006). We highlight key features that are consistent with known processes that occur during the welding of hot pyroclasts and we draw attention to problems associated with interpreting these rocks as hypabyssal intrusions. The rocks in this study exhibit a range of textures that we interpret as reflecting varying degrees of welding intensity. We explore possible mechanisms of welding of kimberlite pyroclasts and discuss how the welding processes and, importantly, how the resulting rock textures differ from those seen in welded rocks of silicic volcanic systems. While unambiguous intrusive kimberlite bodies are present in many kimberlite pipes and in the crust (dykes and sills), we conclude that many occurrences of coherent kimberlite found within kimberlite pipes may be better interpreted as welded pyroclastic rocks.

\section{Observations}

Layered with breccias in both pipes are horizons of competent coherent kimberlite (CK) that can reach many tens-of-metres thick. Many CK units have an inequigranular texture comprised of $10-30$ vol. $\%$ pseudomorphed anhedral olivine mantle xenocrysts and euhedral and subhedral pseudomorphed olivine phenocrysts in a variably altered crystalline groundmass composed of olivine, phlogopite, calcite and spinel microcrysts $(<100 \mu \mathrm{m})$ in a clayserpentine base. Olivine crystals have aspect ratios of up to 1:5. A preferred alignment (30$45^{\circ}$ to horizontal) of elongate olivine crystals is present in some units. Olivine crystal abundance varies on a centimetre to metre scale and in several units olivine crystals form diffuse clusters up to several centimetres in diameter. Alteration is variably strong and most olivine crystals have been partly or wholly replaced by serpentine and calcite, or both.

Three main types of groundmass texture are apparent in thin-section. The first is a patchy, globular texture consisting of framework-supported rounded and globular masses of groundmass $(<0.5 \mathrm{~mm})$ and subspherical groundmass-coated grains (olivine crystals or lithic clasts) in interstitial serpentine and calcite. The interstices form irregular pinched domains. Sparry calcite crystals line the exteriors of some groundmass blebs. The second type exhibits a partly holocrystalline inequigranular texture comprised of olivine macrocrysts and phenocrysts $(10-20 \%)$ in a crystalline groundmass of primary kimberlite minerals. Locally present within the groundmass are fine-grained $(\sim 50-100 \mu \mathrm{m})$ irregular, pinched calcite and serpentine domains, similar to the interstices in the first textural type, that 
partially surround small blebs of groundmass or groundmass-coated grains. Some blebs of groundmass appear to have been deformed between crystals and pelletal grains. The third textural type is essentially holocrystalline, uniform-textured and lacks the serpentinecalcite domains.

\section{Interpretation}

$\mathrm{CK}$ in $\mathrm{K} 2$ and $\mathrm{B} / \mathrm{K} 9$ exhibits macroscopic features that together are consistent with a pyroclastic origin. These include: (1) polymict crustal lithic clasts intimately mixed with juvenile kimberlite material; (2) variations in the abundance, composition and grainsize of lithic clasts including the occurrence of internal lithic layers and fabrics within $\mathrm{CK}$; (3) occurrence within layered sequences of volcaniclastic rocks and breccias; (4) gradational contacts with adjacent volcaniclastic rocks. CK shares these characteristics with other types of pyroclastic rocks in kimberlite pipes (e.g., MVK).

We interpret the globular and rounded masses of groundmass and groundmasscoated particles in $\mathrm{CK}$ in $\mathrm{K} 2$ and $\mathrm{B} / \mathrm{K} 9$ as juvenile ash grains, similar to those seen in volcaniclastic kimberlite rocks ("pelletal lapilli' of Mitchell, 1986). The textural relationship between these juvenile grains and the serpentine-calcite domains, which terminate in pinched asymptotic spaces between groundmass regions, is consistent with the latter representing filled porosity between sintered and welded ash particles.

\section{Discussion}

Detailed studies of welded rocks have largely focused on glassy and vesicular silicic pyroclastic rocks. Less attention has been given to more fluid magma types such as basalt, although there are some valuable studies (e.g. Sumner et al. 2005). The problem here is that some features widely held to be diagnostic for welded pyroclastic rocks are the consequence of the very high viscosity of silicic glasses, the extreme sluggishness of the crystallization kinetics and the vesicular character of the pyroclasts. It cannot be assumed that the same dominant characteristics of welded silicic pyroclasts will also be manifest in putative welded kimberlite pyroclasts. Many of the same generic processes might be expected to be very different because kimberlite magmas are likely to have differing physical properties and behaviours. In particular it may be extremely difficult to form glasses from very silica-poor and probably carbonate-rich melts as the melt viscosities are very low. The crystallization kinetics are likely to be very fast, a corollary of the difficulty of forming glass in such melt compositions even in laboratory experiments with quenching rates faster than are typical in nature.

While alteration prevents exact calculation of melt compositions, the likely properties of erupting kimberlite melts can be evaluated. Their silica-deficient character allows high $\mathrm{CO}_{2}$ solubility, predominantly as $\mathrm{CO}_{3}{ }^{2-}$ (Brooker et al. 2001). The melt viscosity will be very low and has been estimated as $<<1$ Pa s by Sparks et al. (2006). Very low melt viscosity is also indicated by the very thin rims $(<100 \mu \mathrm{m})$ around pelletal clasts. Furthermore, the rounded drop-like character to these rims indicates that they were formed by surface tension effects in pure melt (Clement 1973; Dawson 1980; Sparks et al. 2006).

Thus, the welding processes in silicic pyroclasts that involve the long-lived existence of supercooled melt or glass are unlikely to occur in kimberlites. Further if kimberlite magma is broken up into droplets during explosive eruption these droplets can be expected to flash crystallize if cooling by degassing shifts the melt below the liquidus, and all melt will be eliminated if conditions shift below the solidus. We infer that the initial melt in erupting kimberlite magma can have three different forms in depositing pyroclasts: as pure melt (with suspended olivine phenocrysts and xenocrysts), as partially crystallised clasts with some interstitial melt, and in a completely crystalline state. However, the highly viscous glassy state will not occur.

A final property of juvenile kimberlite pyroclasts is that vesicles are typically absent to low in abundance: primary pyroclasts occur as pelletal clasts and poorly vesicular amoeboid lapilli (Mitchell 1986). Their poorly vesiculated character has been 
attributed to phreatomagmatic processes with the magma being quenched before vesiculation takes place (Lorenz 1975). An alternative explanation is that erupting kimberlite melts have such low viscosities that the separation of gas and melt is very efficient due to very rapid coalescence of both bubbles and of the melt phase into liquid drops. The time scale, $\tau$, for such processes is approximately given by the ratio of surface tension to viscosity:

$$
\tau=\mu \mathrm{r} / 2 \sigma
$$

where $\mu$ is the melt viscosity, $r$ is the typical vesicle or drop dimension and $\sigma$ is the surface tension. For $\sigma=0.05-0.17 \mathrm{Nm}$ (surface tension of dacite and basalt magmas, Khitarov et al., 1979; Mangan and Sisson 2005) and $\mu=0.1-1 \mathrm{~Pa} \mathrm{~s}$ (Sparks et al., 2006) and $\mathrm{r}=1 \mathrm{~mm}$ the time scale is $10^{-1}-10^{-}$ ${ }^{4}$ s. This efficient separation process can be observed in the opening of a pressurised lemonade bottle where the dissolved gas propels an exsolving gas liquid mixture into the atmosphere and the liquid drops fall back to the ground and coalesce to form thoroughly degassed liquid.

We suggest that rapid transitions between welded and non-welded facies are probable during kimberlite eruptions. Three contrasted states of the initial melt phase in the magma are envisaged upon deposition following magma fragmentation. Each results in distinct deposit types. The first is where the initial melt in the magma remains pure melt (above the liquidus temperature) through fragmentation. The depositing pyroclasts coalesce almost immediately to form a degassed homogeneous liquid. Ephemeral lava lakes and lava flows could develop within the conduit from this process. This results in the formation of uniform-textured CK. The second state is where initial melt has largely but not completely crystallized during fragmentation, retaining some residual melt. The resulting pyroclasts are difficult to deform but are still sticky and are able to sinter at point contacts by visco-plastic flow. Pyroclasts are deposited at temperatures between the liquidus and the solidus, i.e., the sintering temperature of Gluckman et al. (1975). This results in incipiently welded, porous pyroclastic deposits. The final state is where the initial melt has fully crystallized during fragmentation (subsolidus). The pyroclasts form a porous non-welded granular deposit on deposition (e.g., MVK). Transitions between these states could result in rapid changes in deposit characteristics.

\section{References}

Brooker R.A.; Kohn, S.; Holloway, J.R.; and McMillan, P.F. 2001. Structural controls on the solubility of $\mathrm{CO} 2$ in silicate melts: Part I. Bulk solubility data. Chem. Geol. 174:225-239.

Brown, R.J.; Tait, M.; Field M.; and Sparks, R.S.J.; in press. Geology of a complex kimberlite pipe (K2 pipe, South Africa): insights into conduit processes during explosive ultrabasic eruptions. Bull. Volcanol. doi: 10.1007/s00445-008-0211-4.

Brown RJ, Buse B, Sparks RSJ, Field M, in press. On the welding of pyroclasts from very low viscosity magmas: evidence from kimberlite volcanoes. Journal of Geology.

Gluckman, M.J.; Yerushalmi, J.; and Squires, A.M. 1975. Defluidization characteristics of sticky or agglomerating beds. In: Keairns, D.L. Fluidization Technology. McGraw-Hill, New York 395-422.

Guest, J.E.; and Rogers, P.S. 1967. The sintering of glass and its relationship to welding in ignimbrites. Proc. Geol. Soc. London 1641:174-177.

Dawson, J.B. 1980. Kimberlites and their xenoliths. Springer Verlag, New York, pp 252.

Clement, C.R. 1973. Kimberlites from the Kao pipe, Lesotho. In: Nixon, P.H. Lesotho kimberlites. Lesotho National Development Program 110-121.

Sumner J.M.; and Branney, M.J. 2002. The emplacement history of a remarkable heterogeneous, chemically zoned, rheomorphic and locally lava-like ignimbrite: 'TL' on Gran Canaria. J. Volcanol. Geotherm. Res. 115:109-138.

Sparks, R.S.J.; Baker, L.; Brown, R.J.; Field, M.; Schumacher, J.; Stripp, G.; and Walters, A. 2006. Dynamical constraints on kimberlite volcanism. J. Volcanol. Geotherm. Res. 155:119-137.

Lorenz, V. 1975. Formation of phreatomagmatic maardiatreme volcanoes and its relevance to kimberlite diatremes. Phys. Chem. Earth 9:17-29.

Mangan, M.; and Sisson, T. 2005. Evolution of meltvapour surface tension in silicic volcanic systems: experiments with hydrous melts. J. Geophys. Res. 110: doi:10.1029/2004JB003215.

Khitarov, N.I.; Lebedev, Y.B.; Dorfman, A.M.; and Bagdasarov, N.S. 1979. Effects of temperature, pressure and volatiles on the surface tension of molten basalt. Geochem. Int. 16:78-86.

Mitchell, R.H. 1986. Kimberlites: Mineralogy, geochemistry and petrology. Plenum Press New York pp. 442. 